THE CASE FOR STANDARDS FOR YOUTH IN CUSTODY IN CANADA

\title{
THE CASE FOR STANDARDS FOR YOUTH IN CUSTODY IN CANADA
}

\author{
CARLA CESARONI \\ University of Toronto
}

\begin{abstract}
Canada has no standards, procedural guidelines, or protocols for best practices in the care of youths in custody. This paper argues that clear, enforceable standards are important in defining a benchmark of acceptable practice. It argues that without standards, issues may arise which can create further difficulty for youths who are under the care of the state. It suggests that the current legal framework for standards is insufficient in its enforceability and its clarity. The new Youth Criminal Justice Act (YCJA) provides the Canadian government with a timely and much-needed opportunity to establish standards of care for youths in custody. Indeed, the YCJA contains specific, comprehensive, and relevant provisions that can be seen as laying a firm foundation for standards of care.
\end{abstract}

\section{INTRODUCTION}

Challenging social circumstances are likely to make the adolescence of children who are already vulnerable psychologically or socially even more difficult (Peterson \& Leffert, 1995). Custody, as an acute stressful event, may amplify the psychopathology of already vulnerable youth (Frydenberg, 1997). Two separate yet related phenomena may affect the lives of youth found guilty of offences in Canada.

First, young offenders in Canada are more likely to be sentenced to custody now than in the past (Stevenson, Tufts, Hendrick, \& Kowalski, 1998). For example, the proportion of young offenders sentenced to custody increased from 31\% in 1992-93 to $34 \%$ in 1996-97 (Stevenson et al.). In 1998-99 there was one case resulting in custody for every 97 youths (age 12-17 inclusive) in the general population in Canada. ${ }^{1}$ There is, however, enormous variability from one province to another (Doob \& Sprott, 1996). In Saskatchewan, for example, there was one case resulting in custody for every 47 youths in the province in 1998-99. At the other extreme, in Quebec there was one case resulting in custody for every 220 youths in the general population (Canadian Centre for Justice Statistics, 1999). In addition, the rate of placing youths in custody in Canada is higher than in many other western industrialized countries including the United States (Sprott \& Snyder, 1999), Australia, and New Zealand (Justice Canada, 1998). Most of the cases resulting in custody involve relatively minor charges (Doob \& Sprott, 1999).

This article is derived from portions of a discussion paper that was prepared by Carla Cesaroni; Sheena Scott, Director of Legal Services, African Canadian Legal Clinic; and Judy Finlay, Chief Advocate, Office of Child and Family Service Advocacy, Government of Ontario. It was funded by the federal Department of Justice. The author would like to thank Sheena Scott, Judy Finlay, and Anthony N. Doob for their contributions. The 
preparation of this article was made possible in part by a research grant from the Social Sciences and Humanities Research Council of Canada to A.N. Doob.

Second, Canada has no standards, procedural guidelines, or protocols for best practices in the allocation of custody or the care of those youths who end up in custody. Without standards, disparities continue to exist in the quality of care a young person may receive. These vary from province to province, community to community, and program to program. Thus we put large numbers of youth into custody and, when we do this, we do little to ensure that they are treated well in the custodial facility.

This paper outlines reasons that formal standards can help reduce these problems. It argues that clear, enforceable standards are important in defining a benchmark of acceptable practice-both in terms of which youths are placed in custody and in terms of what happens to them after they arrive in the custodial institution. It suggests that unless there are explicit standards, issues may arise which can create further difficulty for youths who are under the care of the state. It reviews the effect that an absence of standards has had to the operation of institutions in Canada.

Finally, it discusses how a new youth justice bill (the Youth Criminal Justice Act) ${ }^{2}$ contains specific provisions that may reduce the use of custody and can be seen as laying down a foundation for standards for care. It concludes with a discussion of the many challenging realities that exist in the implementation of standards, including mechanisms for enforcement.

\section{WHY DO WE NEED STANDARDS?}

\section{Institutional Risks}

There are issues youths must cope with that are unique to the experience of being in custody. Institutional abuse refers to abuse that has occurred to a child while under the care of the government, in a government-run facility. A report by the Law Commission of Canada, Restoring Dignity: Responding to Child Abuse in Canadian Institutions (2000), describes a litany of physical and sexual abuse of children who lived in institutions that were funded by the government. Evidence from the Commission's report suggests that significant harm has been done to children in institutions that have been created for their benefit. The Law Commission of Canada suggested that key issues which may explain the apparently high rate of abuse of children in Canadian institutions included the following:

1. A significant power imbalance exists between children and those in charge of institutions, one that goes beyond the obvious power imbalance between a child and an adult in a position of authority. Many staff, for example, have the added weight of institutional authority behind them-or the official power of the government.

2. There is little independent monitoring of what goes on inside these institutions. This lack of effective protection of children cannot be attributed to a single, simple cause. In some cases, however, the desire to preserve the good name of the institution takes precedence over a concern for the welfare of the children.

3. Children who live in residential institutions suffer some measure of disconnection, degradation and powerlessness, due to the very nature of institutional life.

Institutional risks include peer-on-peer violence, physical restraint and placement in isolation. Peer abuse and inmate-on-inmate violence appear to be frequent features of custodial life for incarcerated youths according to several Canadian reports and 
reviews (British Columbia Ombudsman, 1994; Doob, 1999; Leschied, Cunningham, \& Mazaheri, 1997; Ontario Ministry of the Solicitor General, 1999; Saskatchewan Children's Advocate Office, 1999). Evidence suggests that some of this violence is condoned or encouraged by staff in custodial facilities for youth. Doob's (1999) study of a sample of incarcerated relatively older young offenders (those 16 or 17 years old when they offended) includes reports of staff involvement in spreading rumours which led youths to assault other youths, turning a blind eye to violence, and bribing youths to assault other youths. There is little doubt that at least some of the violence experienced by youths in custodial institutions is the direct result of behaviour of those paid to serve the needs of youth and society more generally.

The use of extraordinary control measures with youth in custody is necessary at times. These may be used as protective measures, to restrict the movement of a youth, to stop a youth from dangerous or aggressive behaviour, or when there is suspicion of contraband. Intrusive procedures may include manual restraint, mechanical restraint, isolation, and personal searches. Though some restraint is clearly necessary at times, between 1998 and 2000 in Ontario, two children died in group homes following manual restraint (Mitchell, 2000). Youths describe in detail practices of restraint they perceive as unsafe, inconsistently applied, and excessively forceful. For example, youths report incidents that involve a youth's having their head slammed on concrete, being kicked after being immobilized, being dragged while hog-tied, having a knee pressed to their throat, having a broom handle across the neck, and being pulled downstairs face down (Ontario Office of Child and Family Service Advocacy, 1992, 1998). They frequently report injuries (Ontario Office of Child and Family Service Advocacy, 1998). Doob (1999) notes that $54.1 \%$ of his sample $(n=100)$ of older young offenders in Ontario report witnessing what they considered to be excessive use of force by a guard in the handling of another inmate.

One of the best illustrations of excessive use of force with youths in custody are incidents which are reported to have occurred following a riot in an Ontario youth facility. On February 29, 1996, there was a riot by some youths at Bluewater Youth Centre during a strike by the Ontario Public Service Employees Union. Forty youths were sent to Elgin-Middlesex Detention Centre in London, Ontario. During their transfer and on arrival, several abusive acts by prison staff against youths were reported to have taken place: chunks of hair were ripped from scalps; youths were punched in the face, head, and stomach; youths were struck with batons and forced to lie naked on cold cell floors; some youths were placed in dirty cells in their underwear 24 hours a day and were kicked while there; some youths were placed in isolation for up to 17 days. No youths were provided with medical attention, adequate bedding, or showers (Bessner, 1998).

Youths, perhaps understandably, are often reluctant to lay charges against staff for fear of reprisals (Ontario Office of Child and Family Service Advocacy, 1992, 1998). The question, then, is what can be done to address these problems.

\section{Youths in Custody as an Especially Vulnerable Group}

Standards for determining whether children in care are being properly served must be derived from an understanding of the rights of children in our society (Tho-mas, 1982) and the nature of the children in custody. The need for minimum requirements regarding a young person's basic needs (food, clothing, health care, education) may 
seem apparent. Addressing the provision of these basic necessities, minimizing the risks of being under institutional care, and meeting the special needs of children can be seen as being consistent with the rights accorded to all young persons. However, in the case of young people who are in custody for criminal offences, they are especially important since they are also central to the rehabilitation and reinte-gration into society of young people who have been in conflict with the law-long seen as goals of the youth justice system.

Presumably, a standard that suggested that a young person should not leave an institution in worse condition than when they entered would elicit broad agreement. However, given what we know about the potentially harmful effects of imprisonment on young people (Bartollas, 1982; Biggam \& Power 1997, 1999; Liebling, 1999), avoiding harm may be more difficult than it would appear.

What we know about the young offender population demonstrates that these youths are already vulnerable and require the best standard of care. We know that young offenders are very likely to have been involved in the child welfare and mental health systems prior to their incarceration (Doob, Marinos, \& Varma, 1995). The presence of psychiatric disorders in incarcerated youth appears to be very common. In one study, approximately $85 \%$ of incarcerated youths were found to have at least one diagnosed psychiatric disorder (Ulzen \& Hamilton, 1998).

In addition many indicators of family adversity are associated with incarceration status, including poor parental supervision, parental neglect and abuse, harsh and erratic discipline, parental conflict, exposure to domestic violence, and separation from parents (Farrington, 1997; Spatz Widom, 1997; Ulzen \& Hamilton, 1998). Educational risk factors also indicate that incarcerated youths are particularly vulnerable. For example, low levels of school commitment and poor academic achievement are associated with delinquency (Farrington, 1997). Bortner and Williams (1997) suggest the following about imprisoned youth:

Most have histories of abuse, rejection and failure within their families, schools, and general society. Second, great variation exists among imprisoned youths in terms of their delinquency histories, personal propensities, and future possibilities. Finally, by virtue of their experiences on the streets and in prisons, imprisoned youths are unlike many youths, but they are also similar to other youths in their immaturity, vulnerability, and lack of decision-making abilities (p. xii).

If youths enter institutions having already experienced a significant amount of personal adversity, basic needs and risks that they must face while in the institution become much more relevant to understanding their long-term trajectories.

Sometimes addressing simple needs effectively can reduce other risks a youth faces in custody. For example, the quantity of food available to youth in custody is critical, not only because of the physical needs of growing youth but also because restricted access to food can be a factor in bullying behaviour (Leschied et al.,1997). Food is often the leading non-contraband item perceived as desirable by bullies within a correctional facility (British Columbia Ombudsman, 1994).

\section{The Conditions of Youth Custody Facilities ${ }^{3}$ and the Impact of Imprisonment on Youth}

The current literature highlights the necessity of proper health care for youth in custody. According to the American Medical Association Council on Scientific Affairs, 
incarcerated youth represent a medically under-served population even though prisoners in the United States are the only group to have constitutional guarantees of adequate health care (AMA-CSA, 1990). The AMA suggests that youths in custody have a substantial number of pre-existing health problems and often develop acute problems that are associated with treatment on arrest and the environment of the correctional facility. Berkman and Lippold (1982) argue that though health problems of youths entering the youth justice system may contribute to their problematic behaviour, such problems are rarely treated. The authors note that data on referral and treatment of youths in institutions suggest that facilities generally attend to emergency problems while neglecting problems that do not require immediate attention.

Many facilities in Canada do not identify the educational component of programming as relevant or associated with the overall needs of youth (Leschied et al., 1997). This is unfortunate, since youths who are good at school or who value school or report positive interactions with schoolteachers are more likely to be resilient against delinquency (Smith, Lizotte, \& Thornberry, 1999). According to Rosenbaum (1999), the vast majority of youths entering custody have significant educational deficits. As Rosenbaum suggests, failure to overcome these deficits will make it particularly difficult for these young people to find employment and success-fully reintegrate into their communities once released.

The physical surroundings of youths in custody should not be ignored. Some descriptions of youth facilities do not even approximate the "standard" that was set out in the 1908 Juvenile Delinquents Act. That act stated that "the care and custody and discipline of a juvenile delinquent shall approximate as nearly as may be that which should be given by his parents" (s. 38). Leschied et al. (1997) note that the physical design of an institution can affect safety in many ways, either positively or negatively. Some facilities may be sites of high levels of violence simply because they are designed in such a way that staff cannot monitor all activities of the residents (Leschied et al.). The jury at the inquest into the death of James Lonnee heard evidence that in order to prevent peer-on-peer violence, the architectural design of youth detention facilities must ensure unimpeded lines of vision to allow for surveillance of all areas, especially those identified as high-risk (Ontario Ministry of the Solicitor General, 1999).

For many young offenders, incarceration is likely to be the most significant period they have spent away from family and friends (Biggam \& Power, 1997). Family, friends, and the community play a critical role in the successful rehabilitation and reintegration of the youthful offender (Biggam \& Power, 1997). Maintaining contact with significant others while incarcerated is important to an inmate's adjust-ment and eventual release and is one area in which standards could provide clear guidelines for best practices.

Perhaps one of the most obvious areas of concern would be the right of a young person to be safe and secure in a custodial facility. Peer-on-peer violence appears to be a reality of institutional life. Much of the criminological literature on youths in custody focuses on "bullying" or the victimization of inmates by their peers (Beck, 1995; Connell \& Farrington, 1996; Dyson, Power, \& Wozniak, 1997; Mutchnick \& Fawcett, 1991; Shields \& Simourd, 1991).

On the basis of an analysis of more than 900 detention centres in the United States, Parent et al. (1994) calculated the rate of peer-to-peer abuse in detention settings to be 3.6 incidents of violence per 100 youths over 30 days. According to the 
Howard League's commission of inquiry into violence in penal institutions for teenagers (Howard League for Penal Reform, 1995), the "nature of prison life breeds bullying. . . . Violence and aggression are entrenched as normal behaviour. . . . Those not inclined to violence before entering prison are forced to use it to survive" (p. 13).

Peer victimization can, of course, occur in schools and local neighbourhoods. Peer abuse within custody centres differs significantly from peer abuse in other settings, however, because "youth who are captive and cannot extricate themselves from the circumstances have little hope of escape or relief from abuse" (British Columbia Ombudsman, 1994, p.4). According to Leschied et al. (1997), peer-to-peer violence can occur in the context of intimidation, extortion, stealing, destruction of personal possessions, and/or verbal abuse. The authors suggest that the consequences for the victims include not only physical injury but also psychological distress which manifests itself in an inability to sleep, attempts to escape, and, in extreme cases, suicide. A study by McCorkle (1993) suggests that level of fear is an extremely im-portant predictor of general well-being for prison inmates. As Shields and Simourd (1991) suggest, "The violence which is inherent in predatory relationships poses a threat to safety to the nonpredatory population and renders a correctional facility more difficult to manage" (p. 181).

In a study by Rabb and Rindfleisch (1985) of 630 caregivers in various youth institutions, the majority held the perception that although institutions have a greater responsibility for physical care and supervision than do parents, these caregivers expected less of institutional staff when it came to emotional care and control of youth. Clearly, since these are children who have been placed, against their will, in an institution run by or for the state, staff within all facilities have a duty to attend to both physical and social-emotional needs in a supportive and rehabilitative fashion.

The need for caring and careful treatment extends to circumstances in which extraordinary control measures are required. According to Crespi (1990), few guidelines exist with regard to the possibly hazardous use of restraint and isolation measures experienced by youth. Maltreatment of youths through the overuse of physical restraint is still common in some jurisdictions (AMA-CSA, 1990). Current research has found significant variability in use of control measures which cannot be attributed to the severity of a youth's problems or the restrictiveness of the setting (Persi \& Pas-quali, 1999). Less experienced staff are more likely to use physical control to manage disruptive, aggressive behaviour (West, 1997).

It should be noted that staff brutality is among the factors that may lead to an increase in an offender's propensity for violence, particularly in an offender who has significant psychiatric problems and/or a traumatic history (Kupers, 1996). There are distinct problems associated with exposure to violence by youths including difficulties with emotional regulation, an increase in aggressive behaviour, increased negative selfimage, symptoms of post-traumatic stress disorder, and difficulties in inter-personal relationships (Osofsky, 1995).

Peer-on-peer violence is just one aspect of institutional life that youths must learn to cope with. Adjusting to everyday life in an institution is a stressful event for most youths. Frydenberg (1997) notes that being put in prison is third on the list of severe lifetime stressful events, just behind the death and divorce of parents. Perhaps it is not surprising, therefore, that adolescents in custody are at high risk for both suicide attempts and suicides (Rohde, Seeley, \& Mace, 1997). Primary causes for jail suicide 
include a fear of the unknown, distrust of an authoritarian environment, lack of apparent control over the future, isolation from family and significant others, shame of incarceration, and the dehumanizing aspects of incarceration (Hayes, 1997). Most selfharm is connected to the fear of bullying and/or isolation from families and friends (Howard League for Penal Reform, 1995).

IMPLICATIONS OF THE LACK OF STANDARDS

Thus far, I have made the following points: (a) Custody is heavily used in Canada; (b) youths in institutions are inherently vulnerable because of their powerless position; (c) there are special risks that youths in custody experience such as high levels of violent victimization; (d) some youths in custody are deprived of what are normally considered to be "basic" needs; (e) compared to other youths, these youths are vulnerable because of a high level of psychiatric problems and difficult family backgrounds; (f) imprisonment is a particularly stressful experience for youths. The question that needs to be addressed is a simple one: In what way are these problems exacerbated by a lack of explicit standards?

Ideally, youths in custody should be treated consistently across a variety of settings and circumstances, whether they find themselves in pretrial detention, in an open or secure custody facility, or being transported between facilities and to court. Nevertheless, incidents of lapses in care have been reported in a number of investigations into institutional abuses in Canadian facilities (Bessner, 1998; British Columbia Ombudsman, 1994; Doob, 1999; Law Commission of Canada, 2000; Leschied et al., 1997; Ontario Ministry of the Solicitor General, 1999; Ontario Office of Child and Family Services Advocacy, 1992, 1998; Saskatchewan Children's Advocate Office, 1999). They provide disturbing testimony to what can happen.

At the same time, there is evidence to suggest that standards are lacking in several areas of practice. In a series of reviews of custody settings conducted by the Ontario Office of Child and Family Service Advocacy between 1992 and 1998 and by the Saskatchewan Children's Advocate Office between May 1997 and July 1998, advocates and youths themselves reported several areas of concern including youth-staff interactions, discipline, use of intrusive measures, physical accommodation, food, programming, crowding, and the use of police cells. A review of more specific concerns follows. Without clear minimum standards, those working in the youth justice system have no standard against which to evaluate what is being done to, or for, youth.

\section{Food and Proper Health Care}

Youths frequently complain that the quality of food in most facilities is dismal and the quantity extremely limited (British Columbia Ombudsman, 1994; Ontario Office of Child and Family Service Advocacy, 1992; Saskatchewan Children's Advocate Office, 1999). The quality of health care young people in custody are receiving is also a frequent concern. Youths in custody facilities have reported that medical staff were not always accessible or responsive to their needs and that medical care is not generally available in the evenings or at night (British Columbia Ombudsman). According to Leschied et al. (1997), clinical staff, including psychologists, social workers, chaplains, and medical practioners, are not readily integrated into the larger staff culture of correctional facilities. A suggestion that "adequate" food and health care services should be provided does not tell those responsible for providing them whether a certain 
level of performance is adequate. The more explicit the standard becomes, the easier it becomes to see whether it is being met.

\section{Education and Programming}

For many youths in custody, attendance at school is an important part of programming (Leschied et al., 1997). As suggested previously, many facilities do not identify the educational component of programming as relevant (Leschied et al.). Research has demonstrated that up to $75 \%$ of young offenders have some sort of learning disability and other cognitive deficits for which little if any effective remediation is being provided (Henteleff, 1999). Generally, facilities offer youths a variety of programs designed to provide some learning experiences while keeping them active and engaged (British Columbia Ombudsman, 1994). There are, however, complaints regarding the poor quality of educational programming and the lack of accreditation available for education (Saskatchewan Children's Advocate Office, 1999).

Youth facilities often "offer a patchwork quilt of programs that depend on the availability of the resource persons, the varying talents of the staff and the personal priorities of administrators" (British Columbia Ombudsman, 1994, p. 27 ). There appears to be a "lack of staffing resources required to provide the essential, fundamental, rehabilitative opportunities for youth" (Ontario Office of Child and Family Service Advocacy, 1992, p. 25 ).

If, for example, a "standard" of education were adopted that said that youth in custody were to have the same educational opportunities as same-age youth in the community in which the facility was located, it would be relatively easy to see whether the "standard" was being met. The suggestion that "adequate" educational opportunities need to be provided is almost impossible to operationalize.

\section{Physical Environment}

The physical environment of some youth facilities have been described in the following words: "Dirty moldy bathrooms," "carpeting is stained and damaged," "walls are filthy," "holes in the walls that are unsafe," "furniture is damaged, in poor repair or dirty," "many bedrooms are cold and draughty in the winter" (Ontario Office of Child and Family Service Advocacy, 1992, p. 8). Both government-operated and privately run youth agencies often house young people in deficient buildings, according to the British Columbia Ombudsman (1994). Overcrowding has provided ideal conditions for peer abuse and tensions-doubling up of rooms designed for one, sleeping on the floor or sleeping in storage rooms because no space is available, and disruption of programs, education, and recreation because of insufficient staff (British Columbia Ombudsman; Saskatchewan Children's Advocate Office, 1999).

What constitutes "adequate" physical facilities? In many areas of life, "adequate" physical facilities are defined physically. Temperature, hours of recreation, space, and other requirements can all be defined in explicit terms. Occupational and environmental standards are commonplace and, when there is a will to enforce them, they can be enforced since there is a standard against which current practice can be measured.

\section{Contact with Family and Friends}

In most custody centres visiting is severely restricted (British Columbia Om- 
budsman, 1994). Often only immediate family members are permitted to visit, and visiting hours are limited to specific periods of time that fit in with the facility's schedule (British Columbia Ombudsman). Overcrowding and a lack of facilities close to one's community often interfere with the placement of youths close to their homes and increase the difficulty for youths in maintaining meaningful contact with their families (Saskatchewan Children's Advocate Office, 1999). As distance increases, the opportunities for visiting decrease, especially when poverty is a factor (Saskatchewan Children's Advocate Office).

Telephone contact may be made cumbersome and expensive for youths and their families as institutions may require that long distance calls be made on a collect basis (Saskatchewan Children's Advocate Office, 1999).

In this area, as in others, the question that needs to be asked is simple: What are we attempting to accomplish? Do we want youths who are likely to be returning to their families to maintain community ties? Do we want to minimize the isolation of youth? Clearly the amount of contact cannot be unlimited. Should the amount of contact be left to the whim of local custom or do we want a standard (e.g. a number of minutes per week on the telephone) that is enforceable?

\section{Respect for Rights}

The following problems have been reported consistently in youth facilities: lack of privacy in washrooms and dormitories; staff talking to youth in ways that devalue them (disrespectful comments, swearing, verbal abuse, name-calling, and racial slurs); and staff sharing confidential information with other inmates, which may in turn compromise a youth's safety or self-esteem (British Columbia Ombudsman, 1994; Doob, 1999; Ontario Office of Child and Family Service Advocacy, 1992, 1998; Saskatchewan Children's Advocate Office, 1999). If these behaviours are seen as inappropriate, is there, in each province or in Canada as a whole, a standard that can be pointed to that makes it clear that they are not to be tolerated?

\section{The Multiple Needs of Diverse Populations}

Though standards for youth should apply to all, there are populations within youth facilities that require special sensitivity in their application. Some of these young people's special needs are not being properly addressed.

For example, Aboriginal children continued to be overrepresented in correctional facilities in the 1990s (Commission on Systemic Racism in the Ontario Criminal Justice System, 1995; Law Commission of Canada, 2000). Young Aboriginal offend-ers are often separated by some distance from their home communities and from rele-vant, culturally appropriate, and necessary programs and services (Glanville, 1995).

Special standards for Aboriginal offenders are not unheard of in the justice system. In the sentencing of adult offenders, judges are explicitly supposed to give special consideration to the circumstances of Aboriginal offenders in Canada when searching for noncustodial sanctions at sentencing (Criminal Code, s. 718.2[e]).

A consistent complaint of prisoners-male and female, adults and youths, black and white-is that correctional officers punish black prisoners more frequently, more severely, and for less reason than white prisoners. Correctional officers express many of the same concerns (Commission on Systemic Racism in the Ontario Criminal Jus- 
tice System, 1995).

Youth justice systems are essentially designed for boys and are based on assumptions, concepts, and explanations about offending boys (United Nations Children's Fund, International Child Development Centre, 1998). One consequence is a shortage of resources when dealing with girls in detention. Girls are more likely than boys to be deprived of educational opportunities when detained and, as is common with all women in custody, the special hygiene needs of girls are notoriously subject to being overlooked (United Nations Children's Fund, International Child Develop-ment Centre). A substantial number of female young offenders are mothers (Shaw, 1991) and incarceration can have dire effects for both mother and child. There is evidence that female youthful offenders demonstrate higher rates of prior abuse (especially sexual abuse) than their male counterparts and even adult female offenders (Shaw).

Highly disturbed young people, who may be a danger to themselves and others, may manifest their psychopathology through a variety of symptoms which may be interpreted and serviced differently by a wide range of social agencies. Thus their mental health needs may not be well recognized, widely understood, or adequately met. Availability of appropriate levels and types of expertise and resources tends to be patchy and limited in most secure settings for youth (Kurtz, Thornes, \& Bailey, 1998).

We are currently sending more youths to custody in this country. Many of them are vulnerable youths who face additional adversity in the institutions that have been built to rehabilitate them. Are there remedies to the current situation? At the moment, there are no explicit rules that one can point to which suggest that the different special needs of special groups need to be addressed.

\section{THE NEW LAW: ITS INFLUENCE ON CUSTODY AND DETENTION}

Currently, the Constitution, international instruments, laws relating to civil and criminal liability, and domestic legislation form a patchwork of legal obligations. ${ }^{4}$ As is evident from issues such as those already described that continue to arise in young offender facilities, these obligations are insufficient in their clarity, scope, and enforceability.

In May 1998 the federal minister of justice announced a "Strategy for the Renewal of Youth Justice" which included a proposal to replace the Young Offenders Act. The resulting Youth Criminal Justice Act (YCJA) died on the order paper when the 2000 general election was called, but it has since been reintroduced and passed. It differs dramatically from the YOA in a number of areas including its purposes and principles of custody and supervision. The YCJA contains contain specific and relevant provisions that can be seen as laying a foundation for standards of care.

Two areas of particular concern have been identified under the YOA: the overuse of youth courts for minor offences and overuse of custodial dispositions for youth (Doob \& Sprott, 1999). The Youth Criminal Justice Act addresses these problems by providing more explicit tests for the use of court and of custody. Unlike the YOA, which merely delineates conditions for custody, the YCJA proposes an explicit statement of the purpose and principles of custody. 
The YCJA states that a judge shall not commit a youth to custody unless at least one of four conditions is met (s. 39[1]). Under the YOA the presumption against custody is much less clear-a young person should be held accountable to the victim and society through noncustodial dispositions "whenever appropriate" (s. 24[1.1]). In addition, in order to require reintegration into the community, the nature of custodial sentences is changed so that youth spend one third of their sentence on supervision in the community (s. 39[8]).

These changes, if they are implemented and administered effectively, could change the number as well as the type of youths coming into custody. Of course, with some added effort, the new law could be administered as badly as many say the YOA has been. But the increase in the amount of legislative guidance contained in the new bill is, no doubt, an attempt to constrain discretion. Therefore, with sentencing provisions that are much more explicit than they have been in the YOA, it should be much harder to administer the new law in the same manner as the YOA has been administered in most parts of Canada.

While the new law is more explicit in its purposes and principles of sentencing, it is also clearer on its view of a youth's rights, and of custody and supervision. The preamble sends a clear message regarding the use of custody in that it suggests that the new act "reserves its most serious intervention for the most serious crimes and reduces the over-reliance on incarceration for non-violent young persons."

The YCJA includes a clear statement regarding a youth's rights and freedoms. In the preamble to the YCJA, the legislation explicitly refers to the UN Convention on the Rights of the Child "and recognizes that young persons have rights and freedoms, including those stated in the Canadian Charter of Rights and Freedoms and the Canadian Bill of Rights, and have special guarantees of their rights and freedoms." The mention of these documents in the preamble informs the content of the legislation and confirms the values embraced by Canadian society. It should be noted that the UN Convention on the Rights of the Child covers the entire range of rights and entitlements of children including children in custody. Specific articles are devoted to youth in the justice system and include the protection of basic legal rights, safety, privacy, and promotion and reintegration.

Finally, the YCJA contains provisions that facilitate and encourage reintegration planning. Of specific relevance is section 90, which mandates the designation of a youth worker to help the youth plan for his or her reintegration. Section 91 of the YCJA gives the provincial director the discretion to grant reintegration leaves. As part of the exercise of the federal government's responsibility for criminal law, the YCJA provides a rationale and a framework for standards of care for youth in custody consistent with its preamble, principles, and provisions. The legislation delineates a number of minimal obligations that administrators must fulfill for youths, including providing a safe environment, a rehabilitative plan, and fair and timely reviews. Under the new bill, a youth has the right, codified in the legislation, to a designated youth worker who shall assist in a the preparation and implementation of a plan of care, without delay (s. 90[1]). No such provision exists in the YOA. Provisions like these will make it easier to see if standards have or have not been met.

\section{Making Standards Work}

The problem with the existing broad-based legal framework, including the 
Constitution and domestic and international legislation, is that it is unenforceable. Though the YCJA is a significant improvement on the YOA in terms of tenets of best practice, it does not lay down codified, enforceable standards per se. For example, there are no guidelines set down for the minimum amount of allowable food, education, clothing, and health care.

On the other hand, the "standard" that a "responsible person" should be searched for to supervise a young offender who would otherwise be held in pretrial detention is enforced by requiring the judge to inquire as to the availability of such a person (s. $31[2])$. The YCJA also specifies that a custodial sentence that does not meet one or more of the four conditions for custody in section 39(1) is an illegal sentence-in contrast to the YOA, which simply says that for minor offences youths should be held accountable through noncustodial dispostions "when appropriate" (s. 24[1.1][b]). Without explicit statements of this type, there is little guarantee that there will be any measurable improvement in the selective use of custody.

\section{DIFFICULTIES IN IMPLEMENTING STANDARDS}

We know that problems currently exist in youth offender facilities. It is unlikely that anyone would condone the problems that have arisen. Without explicit performance standards, however, it is difficult for an institution to tell whether it has met a required minimum. It is also easier for facilities and administrators to defend against lax practices. According to the Saskatchewan Children's Advocate Office (1999), procedures and standards are not generally adhered to by staff for three reasons: (a) lack of willingness by staff to be compliant; (b) circumstances such as physical capacity or staff overload that interfere with the ability to be compliant; and (c) lack of awareness by staff of required procedures. One could suggest that there is often a fourth reason: It is impossible to determine whether the standard has been met.

Currently, the primary sources for protecting the basic needs and safety of youth in custody are statute and policy. Statutory protections are typically vague and institutional policy is not binding or enforceable. The YOA is virtually silent in terms of substantive protections. The rights of youth are typically found in provincial legislation. For example, in Ontario these rights are grounded in the Ministry of Correctional Services Act and the Child and Family Services Act.

Apart from dealing with privacy and mail, statutory rights do not offer guidance to youth or service providers in terms of how the rights should materialize. They only describe minimum entitlements in vague language. This places too much discretion in the hands of the facility and too little bargaining power in the hands of the advocate. Youths have potential remedies in court by way of "judicial review" or the use of administrative discretion.

The courts have established procedural rights for persons dealing with administrative decision-making, and the Supreme Court of Canada held in Baker v. Canada (M.C.I.) in 1999 that where children are the subject of administrative decision-making, the best interests of the child must be a factor. Referring to what is best for children without defining it leaves the courts without guidance: Sound best practices need to be articulated to offer this guidance. The costs and complications of litigation are high for a youth who has been aggressively restrained. Where rights are permissive, attempts to review the decision beyond the institution are virtually futile. 
Youths can rely on the Charter in an attempt to correct mistreatment and to create minimum or best-practice standards. The case of $R$. v. McT. met with success in this regard. The holding cells at the courthouse were found to be substandard, small, and unsanitary. The guards did not have expertise with youth. As a result of the case, the government was required to build a youth-friendly and safe environment, which it did. Substandard conditions continue to exist elsewhere, however, and any improvements as a result of this case were localized.

The ministries responsible for young offenders have policy manuals with some standards and procedures in them. Some are fairly detailed. Policy, however, is not legally binding on any of the persons involved. Further, policies are frequently ignored because of attitudes of staff, ambiguity, or ignorance of policy. Often these policies are not known to those most affected by them: the youths in custody. Advocates are left with limited tools in terms of advocating for appropriate conditions and treatment. The limitations of judicial review and ad hoc Charter litigation apply equally. Without clear, system-wide standards, subject to expeditious enforcement mechanisms, any improvements will continue to be sporadic and on the whole insufficient.

What would standards look like? Perhaps the performance-based standards for juvenile correction and detention facilities provide some direction. The Office of Juvenile Justice and Delinquency Prevention (OJJDP), using standards set forth by the American Correctional Association, the National Commission on Correctional Health Care and the American Bar Association, surveyed 984 U.S. youth facilities housing 65,000 youths (Parent et al., 1994). They found that conformity to nationally recognized standards did not necessarily result in improved conditions for youths in custody, in particular with regard to injury rates, escape rates and suicidal behavior.

They noted that many standards emphasized procedural regularity but did not specify outcomes that should be achieved. The OJJDP's recommendations included the development of nationally recognized standards for youth facilities with measurable performance indicators that could serve both as goals for facilities and as benchmarks against which progress could be measured. The lesson is that the standard set should be the standard one wants to achieve.

The survey resulted in the Performance-Based Standards project-a Web-based project (http://www.performance-standards.org.standards.htm) aimed at developing and implementing performance standards at 57 youth detention and custodial facilities in 20 states. Forty youth justice practitioners and experts formulated 22 performancebased standards covering six areas of facility operation: security, order, safety, programming, health, and mental health and justice. They limited the scope of the standards to a small number of meaningful goals and to outcomes that lie within a facility's control. Facilities' performance is evaluated through the collection of outcome measures, processes, and expected practices that relate to each standard. Facilities conduct regular self-assessments using a tool developed by the project to show how their performance improves over time and in comparison to other facilities.

The project's initial successes have included an overall reduction of time in segregation, a reduction in incidents of violence, and better medical and substanceabuse screening. Participation in the program is voluntary, and getting front-line staff to buy into the process has not been without its difficulties.

\section{CONCLUSION}


Thomas (1982) suggests that when the state assumes responsibility for a child it must be held accountable for far stricter standards than are the parents who normally care for children. Holding the state accountable means, however, that there needs to be a standard against which to measure performance.

The legislative program to replace the YOA provides the Canadian government with a timely and much-needed opportunity to establish standards of care for youths in custody. The legislation provides the framework for these standards. The next step would be to develop and implement explicit measurable standards.

\section{NOTES}

1. A "case" is defined as one or more charges against a young person which are first presented in court on the same date. A single young person can be involved in one case at one part of the year (e.g., two thefts in January) and then return to court for another independent set of charges later in the year (e.g., an assault in August).

2. The Youth Criminal Justice Act has had a difficult birthing process thus far. The bill proposing the new act was introduced twice in the 36th Parliament and died on the order paper at the end of each session (the second time when the 2000 general election was called). The Government of Canada reintroduced the bill in the 37th Parliament (first reading February 5, 2001). It was passed by the House of Commons on May 29, 2001, and by the Senate on December 18.

3. Clearly youth custody facilities, like youth themselves, vary enormously. I am not attempting to describe "typical" youth custody facilities, nor am I suggesting that all, or even most, youth facilities are seriously "deficient," however that term might be defined. Rather, I am suggesting that some facilities are below virtually any standard that a civilized society would tolerate and that without explicit standards, it is difficult to raise these facilities to an adequate level.

4. The discussion paper from which this article has been derived contained a substantial discussion of key legal instruments as they pertain to standards of care. Copies of that paper may be obtained by contacting the author.

\section{RÉSUMÉ}

Jusqu'à maintenant le Canada n'a jamais établi des normes de qualité, des directives administratives ou des marches à suivre en ce qui a trait à la détention des jeunes contrevenants et contrevenantes. Cet article soutient que des telles normes constituent pourtant une facette importante de l'élaboration d'un modèle adéquat pour les pratiques correctionnelles relatives aux mineurs et mineures. En effet, l'article trouve que l'absence ou l'insuffisance de ces normes favorisent l'apparition de problèmes additionnels pour ces jeunes placés sous la responsabilité de l'État, et jusqu'à maintenant le cadre juridique en place a souffert à la fois d'un manque de clarté et de difficultés d'application. Cela dit, la toute nou-velle Loi sur le système de justice pénale pour les adolescents offre une splendide occasion d'établir des normes claires et uniformes pour la détention de mineurs et mineures, puisqu'elle comporte déjà des dispositions explicites et exhaustives qui pourraient servir de point de départ à leur élaboration.

\section{REFERENCES}

American Medical Association Council on Scientific Affairs (AMA-CSA). (1990). Health status of detained and incarcerated youths. Journal of the American Medical Association, 263(7), 


\section{THE CASE FOR STANDARDS FOR YOUTH IN CUSTODY IN CANADA}

987-991.

Bartollas, C. (1982). Survival problems of adolescent prisoners. In R. Johnson and H. Toch (Eds.), The pains of imprisonment (pp.165-179).Thousand Oaks, CA: Sage Publications.

Beck, G. (1995). Bullying among young offenders in custody. Issues in Criminological and Legal Psychology, 22, 54-70.

Berkman, D.J., \& Lippold, R.W. (1982). Institutional neglect of juvenile health needs. In R. Hanson (Ed.), Institutional abuse of children and youth (pp. 65-78). New York: Haworth Press.

Bessner, R. (1998). Institutional child abuse in Canada. Unpublished manuscript.

Biggam, F.H., \& Power K.G. (1997) Social support and psychological distress in a group of incarcerated young offenders. International Journal of Offender Therapy and Comparative Criminology, 41(3), 213-230.

Biggam, F.H., \& Power, K.G. (1999). A comparison of the problem-solving abilities and psychological distress of suicidal, bullied, and protected prisoners. Criminal Justice and Behavior, 26(2), 196-216.

Bortner, M.A., \& Williams, L.M. (1997). Youth in prison: We the people of Unit Four. New York: Routledge.

British Columbia Ombudsman. (1994, June). Building respect: A review of youth custody centres in British Columbia. Public Report No. 34. Victoria, BC: Author.

Canadian Centre for Justice Statistics. (1999). Table 8. In Youth court data tables. Ottawa: Statistics Canada.

Commission on Systemic Racism in the Ontario Criminal Justice System. (1995). Report. Toronto: Queen's Printer for Ontario.

Connell, A., \& Farrington, D. (1996). Bullying among incarcerated young offenders: Developing an interview schedule and some preliminary results. Journal of Adolescence, 19(1), 75-93.

Crespi, T.D. (1990). Restraint and seclusion with institutionalized adolescents. Adolescence, 25(100), 825-829.

Doob, A.N. (1999). The experiences of Phase II male young offenders in secure facilities in the province of Ontario. Toronto: Canadian Foundation for Children, Youth and the Law.

Doob, A.N., Marinos, V., \& Varma, K.N. (1995). Youth crime and the youth justice system in Canada. Toronto: University of Toronto, Centre of Criminology.

Doob, A.N., \& Sprott, J.B. (1996, October). Interprovincial variation in the use of youth court. Canadian Journal of Criminology, 401-412.

Doob, A.N., \& Sprott, J.B. (1999). Changes in youth sentencing in Canada. Federal Sentencing Reporter, 11(5), 262-267.

Dyson, G., Power, K., \& Wozniak, E. (1997). Problems with using official records from young offender institutions as indices of bullying. International Journal of Offender Therapy and Comparative Criminology, 41(2), 121-138.

Farrington, D.P. (1997). A critical analysis of research on the development of antisocial behaviour from birth to adulthood. In D.M. Stoff, J. Breiling, \& J.D. Maser (Eds.), Handbook of antisocial behaviour (pp. 218-233). New York: John Wiley \& Sons.

Frydenberg, E. (1997). Adolescent coping: Theoretical and research perspectives. New York: Routledge.

Glanville, J. (1995). Royal Commission into Aboriginal deaths in custody: A fair deal for young people? Up2Date, 3(11), 8-10.

Hayes, L.M. (1997). Juvenile suicide in custody: A national survey and psychological autopsy study. Alexandria, VA: National Centre on Institutions and Alternatives Jail Suicide Prevention Task Force.

Henteleff, Y. (1999, September 27). The learning disabled child-at-risk: Why youth service systems have so badly failed them. Paper presented at Working Together for Children: Protection and Prevention Conference, Ottawa.

Howard League for Penal Reform. (1995). Banged up, beaten up, cutting up: Report of the Howard League commission of inquiry into violence in penal institutions for teenagers under eighteen. London: Author.

Kupers, T.A. (1996) Trauma and its sequelae in male prisoners: Effects of confinement, 
overcrowding, and diminished services. American Journal of Orthopsychiatry, 66, 189-196.

Kurtz, Z., Thornes, R., \& Bailey, S. (1998). Children in criminal justice and secure care systems: How their mental health needs are met. Journal of Adolescence, 21(5), 543-553.

Law Commission of Canada. (2000). Restoring dignity: Responding to child abuse in Canadian insitutions. Ottawa: Department of Public Works and Government Services.

Leschied, A.W., Cunningham, A., \& Mazaheri, N. (1997). Safe and secure: Eliminating peer-topeer violence in Ontario's Phase II secure detention centres. North Bay, ON: Ministry of Solicitor General and Correctional Services, Peer on Peer Violence Initiative.

Liebling, A. (1999). Prison suicide and prison coping. In M. Tonry \& J. Petersilia (Eds.), Prisons (pp. 283-359). Chicago: Univesity of Chicago Press.

McCorkle, R.C. (1993). Fear of victimization and symptoms of psychopathology among prison inmates. Journal of Offender Rehabilitation, 19(1-2), 27-41.

Mitchell, B. (2000, January 12). Inquest to be called in teens' deaths. Toronto Star, p. B5.

Mutchnick, R.J., \& Fawcett. M. (1991). Group home environments and victimization of resident juveniles. International Journal of Offender Therapy and Comparative Criminology, 25(2): 126-142.

Ontario Ministry of the Solicitor General. (1999, April 23). Verdict of the jury at the inquest in the death of James Preston Lonnee. Toronto: Author.

Ontario Office of Child and Family Services Advocacy. (1992). Care of youth at Thistletown Regional Centre Syl Apps Campus. Toronto: Author.

Ontario Office of Child and Family Services Advocacy. (1998). Voices from within: Youth in care in Ontario speak out. Toronto: Queen's Printer for Ontario.

Osofsky, J.D. (1995). The effects of exposure to violence on young children. American Psychologist, 50, 782-788.

Parent, D.G., Lieter, V. Kennedy, S., Livens, L., Wentworth, D., \& Wilcox. S. (1994). Conditions of confinement: Juvenile detention and corrections facilities-Research report. Rockville, MD: U.S. Department of Justice Office of Juvenile Justice and Delinquency Prevention.

Persi, J., \& Pasquali, B. (1999). The use of seclusions and physical restraints: Just how consistent are we? Child and Youth Care Forum, 28(2), 87-103.

Peterson, A.C., \& Leffert, N. (1995).What is special about adolescence. In M. Rutter (Ed.), Psychosocial disturbances in young people: Challenges for prevention (pp. 3-36). Cam-bridge, UK: Cambridge University Press.

Rabb, J., and Rindfleisch, N. (1985). A study to define and assess severity of institutional abuse/neglect. Child Abuse and Neglect, 9, 285-294.

Rohde, P., Seeley, J.R., \& Mace, D.E. (1997). Correlates of suicidal behavior in juvenile detention population. Suicide and Life-Threatenting Behaviour, 27(2), 164-175.

Rosenbaum, S.H. (1999). Civil rights issues in juvenile detention and correctional systems. Corrections Today, 6(61), 148-156.

Saskatchewan Children's Advocate Office. (1999). Issues affecting youth in conflict with the law: $A$ review of issues raised with Saskatchewan Children's Advocate Office. Saskatoon, SK: Author.

Shaw, M. (1991). Ontario women in conflict with the law subsidiary report: Young offenders. Toronto: Ministry of Correctional Services.

Shields, I.W., \& Simourd, D.J. (1991). Predicting predatory behaviour in a population of incarcerated young offenders. Criminal Justice and Behaviour, 18, 180-194.

Smith, C., Lizotte, A.J., \& Thornberry, T.P. (1999). Resilient youth: Identifying factors that prevent high-risk youth from engaging in delinquency and drug use.Current Perspectives on Aging and the Life Cycle, 2(2), 217-247.

Spatz Widom, C. (1997). Child abuse, neglect and witnessing violence. In D.M. Stoff, J. Breiling, \& J.D. Maser (Eds.), Handbook of antisocial behaviour (pp. 148-158). New York: John Wiley \& Sons.

Sprott, J.B., \& Snyder, H.N. (1999). Youth crime in the U.S. and Canada 1991-1996. Overcrowded Times, 10(5), 1-19.

Stevenson, K., Tufts, J., Hendrick, D., \& Kowalski, M. (1998). A profile of youth justice in 
Canada. Ottawa: Canadian Centre for Justice Statistics.

Thomas, J. (1982) The responsibility of residential placements for children's rights to development. In R. Hanson (Ed.), Institutional abuse of children and youth (pp. 23-45). New York: Haworth Press.

Ulzen, T., \& Hamilton, H. (1998). Psychiatric disorders in incarcerated youth. Youth Update, 16(1): 4-5.

United Nations Children's Fund, International Child Development Centre. (1998, January). Are increasing numbers of juveniles committing offences? Innocenti Digest, No. 3 Juvenile Justice, 6-8.

West, K.J. (1997). Client characteristics contributing to the frequency of physical restraints in child residential treatment of males. Residential Treatment of Children and Youth, 14(4), 6373 .

\section{Canadian Case Law}

Baker v. Canada (M.C.I.) (1999), 174 D.L.R. (4th) 193.

R. v. McC. (T) (1991), 40.R.(3d) 203 .

\section{Canadian Statutes}

Charter of Rights and Freedoms, being Part I of the Constitution Act, 1982.

Criminal Code, R.S.C. 1995, ch. 22.

Juvenile Delinquents Act, R.S.C. 1970, ch. J-3.

Young Offenders Act, R.S.C. 1985, ch. Y-1.

Youth Criminal Justice Act, Bill C-7, 2001.

\section{International Instruments}

United Nations Convention on the Rights of the Child adopted and opened for signature, ratification and accession by G.A. Res. 44/25 of November 20, 1989; entry into force September 2, 1990. 